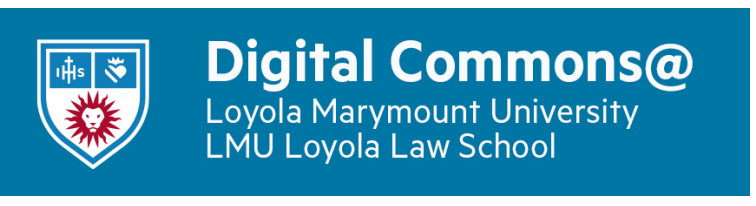

Journal of Catholic Education

$12-1-2008$

\title{
The Effects of Catholic and Protestant Schools: A Meta-Analysis
}

William H. Jeynes

Follow this and additional works at: https://digitalcommons.Imu.edu/ce

\section{Recommended Citation}

Jeynes, W. H. (2008). The Effects of Catholic and Protestant Schools: A Meta-Analysis. Journal of Catholic Education, 12 (2). http://dx.doi.org/10.15365/joce.1202092013

This Review of Research is brought to you for free with open access by the School of Education at Digital Commons at Loyola Marymount University and Loyola Law School. It has been accepted for publication in Journal of Catholic Education by the journal's editorial board and has been published on the web by an authorized administrator of Digital Commons at Loyola Marymount University and Loyola Law School. For more information about Digital Commons, please contact digitalcommons@lmu.edu. To contact the editorial board of Journal of Catholic Education, please email JCE@nd.edu. 


\title{
REVIEW OF RESEARCH
}

\section{The Effects of Catholic and Protestant Schools: A Meta-Analysis}

\author{
William H. Jeynes \\ California State University at Long Beach
}

\begin{abstract}
A meta-analysis was undertaken, including 41 studies to determine the influence of Catholic and Protestant schools. The analysis examined studies undertaken at both the elementary and secondary school level. The results indicate that both Catholic and Protestant school students do better than their counterparts in public schools. In addition, Protestant school students excelled more than their Catholic counterparts on most standardized tests, but Catholic school students did better than their Protestant school counterparts on non-standardized measures. The significance of these results is discussed.
\end{abstract}

\section{Introduction}

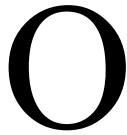

ver the last 40 years, there has been a considerable amount of debate on the effects of religious schools on academic achievement (Bryk, Lee \& Holland, 1993; Chubb \& Moe, 1990; Coleman, 1988; Hoffer, 1997). More than 20 years ago, studies undertaken by Coleman, Hoffer, and Kilgore (1982) as well as other social scientists (Keith \& Page, 1985) indicated that religious school students enjoyed a significant academic advantage over their counterparts in public schools. Even when controlling for socioeconomic status (SES), race, and past achievement, religious school students enjoyed a distinct advantage. The results suggested that the quality of education offered in the schools was the major ingredient behind the "school effect" (Coleman, 1988; Coleman et al., 1982). However, nearly all the studies that have been done on the influence of religious schools have not focused on the differences in the effects of Catholic and Protestant schools (Irvine \& Foster, 1996; Morris, 1994, 1998; Sander, 1996).

Knowing if there are any differences in the pattern of effects for Catholic and Protestant schools would be particularly interesting for a number of reasons. First, it would give insight into whether the influence of religious schools holds across these two major lines of Christian faith. Second, it would help educators to understand whether there are areas that Catholic and Protestant schools can learn from one another. Third, it would help parents and other 
individuals to make individual and policy decisions based on the strengths and weaknesses of Catholic and Protestant schools. Fourth, if Catholic and Protestant schools improve further by learning from one another, it might bolster the chances that the government will encourage the implementation of school choice.

On the basis of research that has been done on the effects of religious faith and schools on various individuals, there are some reasons to think that religious schools may impact academic achievement in a positive way. The first of these reasons, and historically probably the most acknowledged, deals with a religious work ethic. This is the notion that one's service to God often causes one to work more diligently. Research in the social sciences has indicated consistently the existence of a religious work ethic (Furnham, 1987; Gerhards, 1996; Giorgi \& Marsh, 1990; Mudrack, 1992). Busto (1996) and Ter Voert (1993) found that this religious work ethic transcends differences in race and nationality.

A second reason to believe there might be a relationship between religious schools and academic achievement emerges from the tendency for religious schools to help students abstain from behaviors that are often regarded as undisciplined and harmful to academic achievement. A number of studies indicate that religious students and religiously oriented committed teens are less likely to become involved in drug and alcohol abuse (Bahr, Hawks, \& Wang, 1993; Brownfield \& Sorenson, 1991; Jeynes, 2005b; Nylander, Tung, $\& \mathrm{Xu}, 1996)$. Other studies indicate that religiously committed teens are less likely to engage in sexual behavior or become pregnant while they are still teenagers (Beck, Cole, \& Hammond, 1991; Holman \& Harding, 1996; Miller \& Olson, 1988).

A third reason stems from the finding of some studies that suggest that religious people are more likely to have an internal locus of control (Jackson \& Coursey, 1988; Shrauger \& Silverman, 1971). That is, they are more likely to attribute individual success or failure to factors within one's control rather than beyond one's control. Educational researchers have found a rather consistent relationship between possessing an internal locus of control and performing well in school (Garner \& Cole, 1986; S. Johnson, 1992). Whatever the reasons might be for the religious school advantage over public schools, there is a sense that a large percentage of the reasons rest in the school culture (Mok \& Flynn, 1998).

Most of the studies that have been done have focused either on comparing the achievement of students attending religious or private schools versus those going to public schools (Coleman, 1988; Coleman et al., 1982; Keith $\&$ Page, 1985). Most of these studies have focused on the impact of students 
attending private schools versus public schools (Coleman, 1988; Coleman et al., 1982). However, many studies have focused all or part of their attention on religious private schools, in particular (Bryk et al., 1993; Keith \& Page, 1985; Sander, 1996). Of these initiatives, most have directed their attention on studying Catholic schools (Bryk et al., 1993; Keith \& Page, 1985; Sander, 1996). However, in the last 25 years Protestant, primarily Evangelical schools, have constituted an increasing percentage of the total number of religious schools (Jeynes, 2003b).

As a result of the significant contributions of both Catholic and Protestant, mostly Evangelical, schools the question arises as to whether the influence of these types of educational institutions are similar or different from each other (Sander, 1996). Are the academic effects of these schools similar or different overall or across dimensions? Moreover, if any differences emerge, are there any indications that Catholic and Protestant educators have something to learn from each other. If so, the implications of this study may prove particularly salient. If Catholics and Protestants can each improve their educational outcomes by learning from each other, then not only will religious education benefit, but in so doing the potency of the school choice argument will be enhanced (Bryk et al., 1993; Gewirtz, Ball, \& Bowe, 1995). The importance of determining whether there are any similarities or differences between Catholic and Protestant schools, therefore, has two important ramifications. First, the findings can be used to identify areas of strength and weakness in Catholic and Protestant schooling. Second, if these religious schools are amenable to learning from one another and religious schools improve even further, the case for school choice can be fortified (Gewirtz et al., 1995; Jeynes, 2002a).

A growing number of social scientists are appreciating the importance of procuring a greater understanding of Catholic and Protestant education, as it relates to school choice (Bryk et al., 1993; Chubb \& Moe, 1990; Jeynes, 2000, 2002a). Recent research has established that even when one controls for socioeconomic status and race, religious school students have an academic advantage over their counterparts in the public sector (Jeynes, 2002a, 2005a). Moreover, various studies consistently demonstrate that children from lowSES and minority backgrounds perform better in religious schools than they do in private schools (Gaziel, 1997; Jeynes, 2002a, 2003b). This is not merely a pattern that has emerged in particular individual studies, but meta-analyses indicate that this is the trend of the overall body of research (Jeynes, 2002b, $2003 \mathrm{~b}$ ). Given that one of the primary goals of school choice is to help poor and minority students, this finding is especially important (Jeynes, 2002a, $2002 b$ ). Other research on religiosity suggests that personal faith and family stability, which are often a hallmark of Christian homes, also have an 
ameliorative influence on minority students (Brutsaert, 1998; Cochran, 1992; Cochran, Beeghley, \& Bock, 1992; Jeynes, 1999). This research indicates that when minority children are religious and come from intact families, the achievement gap that traditionally exists between White and minority students disappears (Jeynes, 2002a).

This meta-analysis is designed to compare the overall effects of Catholic and Protestant schools on students versus their counterparts in public schools and compared with one another. In addition, those studies that used a category for non-Catholic private schools were also included in the analysis, as a third category, because the majority of non-Catholic private schools are Protestant schools. This meta-analysis will address three research questions. First, what are the effects of students attending Catholic and Protestant schools when compared with public school students? Second, do the effect sizes differ between Catholic and Protestant schools? Third, are there any differences in the pattern of effect sizes for Catholic and Protestant schools?

\section{Methods}

The procedures used to conduct the meta-analysis are outlined under research focus, analytical approach, defining of variables, data collection method, statistical methods and effect size statistics, and study quality rating.

\section{Research Focus}

In the 41 studies included in the meta-analyses undertaken in this paper, attempts were made to address the following questions: (a) How does the academic achievement of students attending Catholic and Protestant schools compare with that of their counterparts in public schools? (b) Are there any differences in the effect sizes for Catholic and Protestant school students versus public school students? (c) Are effect sizes related to types of outcome measures, especially standardized versus non-standardized measures? (d) Are quality, age of the students, or year of study related to effect size in any way?

\section{Analytical Approach}

This meta-analysis examined the relationship between students attending Catholic or Protestant schools and their academic achievement. The first analysis (Model A) included determining overall achievement effect sizes for the 3 groups of school students versus their counterparts in public schools, using all of the studies included in the meta-analysis. These 3 groups of students 
included those from Catholic schools, Protestant schools, and non-Catholic private schools, which were mostly made up of Protestant schools.

Most of the researchers who conducted studies sought to examine the difference in student educational outcomes between those from religious and public schools in its own right. However, some studies examined this difference while controlling for some of the educational emphases that are often used to explain the differences in achievement. For example, some studies controlled for whether a student was placed on a high academic track. Research indicates that religious schools are much more likely than public schools to insist that poorly performing students be placed on an academic track (Bryk et al., 1993). A number of social scientists believe that this policy partially explains the religious school advantage (Bryk et al., 1993; Coleman et al., 1982). It is therefore questionable whether controlling for this variable is appropriate.

The second analysis (Model B) excluded those studies that included variables in their analysis that tended also to capture some of the influence of religious schools. For example, two reasons that social scientists believe that religious school students perform better academically than public school students is because religious schools emphasize that students should take a demanding curriculum and they insist on high levels of parental involvement. Some studies actually add variables for the extent to which schools emphasize a demanding curriculum and parental involvement. However, to the extent that these two factors help explain the religious school advantage, including these variables would tend to dilute the effect sizes for religious schools artificially. The problem with controlling for these variables is that many social scientists believe that the fact that religious schools insist that more of their students are on the academic track and that parents are strongly involved in education are two of the reasons why religious students outperform their counterparts in public schools (Gamoran, 1992; Morris, 1994; Sander, 1996). Therefore, Model B excluded the studies that used the procedure just described.

Each study incorporated in this meta-analysis met the following criteria: (a) It needed to examine Catholic and Protestant in a way that could be conceptually and statistically distinguished from other primary variables under consideration. For example, if a study combined the effects of schooling with other variables in which the influence of each could not be distinguished, this study was not included in the meta-analysis. (b) It must include a sufficient amount of statistical information to ascertain effect sizes. That is, a study needed to possess enough information so that test statistics, such as those resulting from a $t$-test, analysis of variance, and so forth, were either provided in the study or could be determined from the means and measures of 
variance provided in the study. (c) If the study included a control group, it had to qualify as a true control group and, therefore, be a fair and accurate means of comparison. Furthermore, if the research utilized a control group at some times but not others, only the former comparisons were included in the metaanalysis. (d) The study could be a published or unpublished study. Given the nature of the criteria listed above, qualitative studies were not included in the study. Qualitative studies are definitely valuable, but they are difficult to code for quantitative purposes and any attempt to do so might bias the results of the meta-analysis.

\section{Defining of Variables}

For the purposes of this study, attending a religious school was defined as a student attending a private school that was sponsored by a Catholic or Protestant group and was designed to meet certain religious and educational goals.

\section{Data Collection Method (Coding and Rater Reliability)}

In order to obtain the studies to be used in the meta-analysis, a search was performed using every major search engine covering research in the social sciences; this included about 25 databases (Psycinfo, ERIC, Dissertation Abstracts International, Wilson Periodicals, Sociological Abstracts) and every literature review in the United States and internationally of the effects of religious schools and religious commitment was used. The search terms included religious schools, Catholic schools, Catholic, Protestant schools, Protestant, parochial schools, diocese, Evangelical schools, Evangelical, Baptist schools, Methodist schools, Pentecostal schools, Christian schools, religious education, Community Church schools, Church schools, Assemblies of God schools, religious training, Catholic training, parish schools, and other terms, which reflected many different religious denominations. Although this search yielded over 2,000 articles and papers on religious education, nearly all of these articles were not quantitative in nature. Over 50 studies were found that obtained quantitative information, but only 41 studies contained a sufficient amount of quantitative information to be included in the meta-analysis.

\section{Statistical Methods and the Effect Size Statistics}

In order to ensure accurate statistical results, a number of steps were taken to make the meta-analysis more sophisticated. First of all, the Hedges' "g" measure of effect size was used (Hedges, 1981). Since it employs the pooled standard deviation in the denominator, it should give a more conservative estimate of effect size. Hedges also provides a correction factor that helps to 
modify the impact of sampling bias. Effect sizes from data in such forms as $t$-tests, $F$ tests, $p$ levels, frequencies, and $r$ values were calculated via conversion formulas provided by Glass, McGaw, and Smith (1981). When results were not statistically significant, studies sometimes reported only a significance level. In the unusual case that the direction of these not significant results was not available, the effect size was calculated to be zero. The effect sizes were determined using weights based on the inverse of the variance, in order to give greater weight to studies with larger sample sizes.

Statistical analysis was done to determine the overall effects of Catholic and Protestant schools obtained for each study, as well as the specific academic outcomes that attending religious schools affected. These specific academic outcomes include standardized measures (i.e., achievement test outcomes, often identified by specific subject) and non-standardized measures (i.e., grade point average [GPA], teacher ratings, the extent to which students took advanced placement courses, and whether they were left behind a grade). Two statistical measures were used to reduce sampling and publication bias. The studies that this meta-analysis drew from nearly always took into consideration matters of SES, gender, and race by controlling for these factors.

\section{Study Quality Rating}

Two researchers coded the studies independently for quality, the presence of randomization, and whether both the definitional criteria for Catholic, Protestant, and non-Catholic private schools were met. Study quality and the use of random samples were graded on a 0 (lowest) to 3 (highest) scale. Quality was determined using the following: (a) Did it use randomization of assignment? (b) Did it avoid mono-method bias? (c) Did it avoid monooperation bias? (d) Did it avoid selection bias? The author calculated interrater reliability by computing percentage of agreement on the issues of the definition of religious schools, as well as on the issues of randomization and quality of the study. The inter-rater reliability was $100 \%$ for each of the definitions of religious schools and $96 \%$ for whether a random sample was used. The inter-rater reliability was $88 \%$ for the quality of the study.

Two supplementary analyses were done to include (a) only those studies with quality ratings of 2 and 3 and (b) those studies with quality ratings of 1-3.

\section{Results}

The results (see Table 1) of the meta-analysis indicate that in terms of overall academic achievement, Catholic and Protestant school students had very similar advantages over their counterparts in public schools. Table 1 lists 
all the studies included in the meta-analysis in terms of the size of the religious school student advantage over their counterparts in public schools, the first studies listed having large effect sizes, and the later studies listed having smaller effect sizes. The effect sizes ranged from a high of .68 standard deviation units favoring religious (in this case Catholic) school students over public school students, to -.07 standard deviation units favoring public school students over religious (in this case Catholic) school students. The overwhelming number of studies indicated a "religious school advantage." Most of the effect sizes were in the .15 -.30 range.

\section{Research Questions A and B}

The research questions addressed in this section are as follows: (a) How does the academic achievement of students attending Catholic and Protestant schools compare with that of their counterparts in public schools? (b) Are there any differences in the effect sizes for Catholic and Protestant school students versus public school students?

Tables 2 and 3 indicate the extent to which Catholic, Protestant, and nonCatholic (mostly Protestant) school students differed from public school students and also differed from one another. Table 2 indicates that the Protestant school students, made up primarily of Evangelical students, had a .19 standard deviation unit advantage over public school students. Students from Catholic schools had a .17 standard deviation unit edge over their counterparts in public schools. The difference between the effect sizes for Catholic and Protestant students was not statistically significant. The effect size for those studies that only distinguished between Catholic private schools and non-Catholic (mostly Protestant) private schools collectively yielded an effect size of .21 favoring students from non-Catholic private schools over public school students. This advantage over their public school counterparts was not different to a statistically significant degree either from students from Catholic and Protestant school students.

\section{Research Questions C and D}

The research questions addressed in this section are as follows: (c) Are effect sizes related to types of outcome measures, especially standardized versus non-standardized measures? (d) Are quality of the study, age of the students, or year of study related to effect size in any way?

Although no statistically significant differences emerged from overall academic achievement, differences did manifest themselves for distinct measures of achievement. Overall, the effect sizes showed a pattern in which 
Table 1

List of Studies Used in the Meta-Analysis for Religious Schools, the Year of the Study, and the Effect Sizes for the Various Studies

\begin{tabular}{|c|c|c|c|}
\hline Study & Year & $\begin{array}{c}\text { Catholic } \\
\text { school } \\
\text { effect } \\
\text { size }\end{array}$ & $\begin{array}{l}\text { Protestant or } \\
\text { other private } \\
\text { school effect } \\
\text { size }\end{array}$ \\
\hline Graetz & 1990 & +.68 & - \\
\hline Keith \& Page & 1985 & +.39 & - \\
\hline Jeynes (combined) & $2003 a \& 2003 b$ & +.31 & +.22 \\
\hline Lee \& Bryk & 1989 & +.30 & 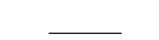 \\
\hline Raudenbush \& Bryk & 1986 & +.30 & 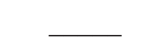 \\
\hline Hoffer, Greeley, \& Coleman & 1985 & +.28 & 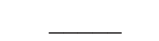 \\
\hline Alexander \& Pallas & 1983 & +.28 & 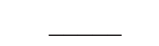 \\
\hline Lee & 1986 & +.27 & 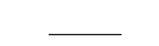 \\
\hline Goldberger \& Cain & 1982 & +.25 & +.28 \\
\hline Lee & $1985 \mathrm{a}$ & +.25 & 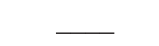 \\
\hline Coleman, Hoffer, \& Kilgore & 1981 & +.25 & 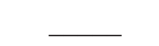 \\
\hline $\begin{array}{l}\text { Taylor, Casten, Flickinger, Roberts, } \\
\& \text { Flumore }\end{array}$ & 1994 & +.23 & 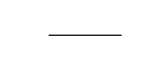 \\
\hline Lee \& Smith & 1993 & +.22 & +.32 \\
\hline Hoffer, Greeley, \& Coleman & 1987 & +.22 & +.28 \\
\hline Lee \& Stewart & 1989 & +.22 & 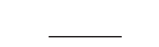 \\
\hline Bauernfeind \& Blumenfeld & 1963 & +.22 & ـ \\
\hline Lee, Chen, \& Smerdon & 1996 & +.20 & +.27 \\
\hline Johnson & 1999 & +.20 & + \\
\hline Lee & $1985 b$ & +.18 & + \\
\hline Perie, Vanneman, \& Goldstein & 2005 & +.17 & +.16 \\
\hline Weaver & 1971 & +.16 & {[} \\
\hline
\end{tabular}

students from Protestant schools did better on standardized test measures and students from Catholic schools did better on non-standardized measures, such as their likelihood of being held back a grade and taking college preparation courses. On standardized test measures, Protestant school students had a .24 standard deviation edge over their public school counterparts, versus the .16 edge that Catholic school students had. This difference was statistically significant at the .05 level of probability. The standardized test advantage for 
Table 1 (continued)

\begin{tabular}{|c|c|c|c|}
\hline Study & Year & $\begin{array}{c}\text { Catholic } \\
\text { school } \\
\text { effect } \\
\text { size }\end{array}$ & $\begin{array}{l}\text { Protestant or } \\
\text { other private } \\
\text { school effect } \\
\quad \text { size }\end{array}$ \\
\hline Marsh \& Grayson & 1990 & +.16 & _- \\
\hline Sutton \& de Diveira & 1995 & __ـ & +.15 \\
\hline Riordan & 1985 & +.13 & \\
\hline Brutsaert & 1998 & +.10 & _- \\
\hline Bryk \& Thum & 1989 & +.10 & 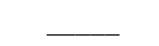 \\
\hline Marsh & 1991 & +.10 & - \\
\hline Alexander \& Pallas & 1985 & +.08 & 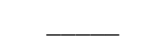 \\
\hline Willms & 1985 & +.05 & _- \\
\hline Hoffer & 1997 & +.04 & - \\
\hline Coleman, Hoffer, \& Kilgore & 1982 & +.03 & +.10 \\
\hline Lee \& Smith & 1995 & +.03 & \\
\hline Willms & 1982 & +.03 & _ \\
\hline Morgan & 1983 & +.02 & +.04 \\
\hline Noell & 1982 & +.02 & L \\
\hline Carpenter & 1985 & +.02 & _ـ \\
\hline Sassenrath, Croce, \& Penaloza & 1984 & +.00 & 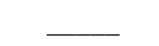 \\
\hline Schneider & 1965 & +.00 & _ \\
\hline Young \& Fraser & 1990 & +.00 & $\ldots$ \\
\hline Bodenhausen & 1989 & -.01 & +.10 \\
\hline Payne \& Ford & 1977 & -.07 & - \\
\hline
\end{tabular}

studies that distinguished only between Catholic and non-Catholic (mostly Protestant), private schools yielded an effect size of .21 standard deviation units. This was different to a statistically significant degree from the effect size for Catholic schools, but not from the effect size for only Protestant schools $(p<.05)$.

The pattern for non-standardized measures, in contrast, showed an advantage for Catholic school students. Catholic school students had an academic advantage of .18 standard deviation units over public school students on these measures. Protestant, mostly Evangelical, school students maintained a .10 advantage over their public school counterparts. The difference between these two regression coefficients was statistically significant at the 
Table 2

Effect Sizes of Catholic, Protestant, and Non-Catholic Private Schools Using Model A

\begin{tabular}{|c|c|c|c|}
\hline & $\begin{array}{c}\text { Overall } \\
\text { Educational } \\
\text { Outcomes }\end{array}$ & $\begin{array}{c}\text { Achievement } \\
\text { Tests }\end{array}$ & $\begin{array}{c}\text { Other } \\
\text { Measures }\end{array}$ \\
\hline Catholic & $\begin{array}{l}.17 * \\
(.04, .30)\end{array}$ & $\begin{array}{l}.16^{*} \mathrm{a} \mathrm{b} \\
(.02, .30)\end{array}$ & $\begin{array}{l}.18^{*} \mathrm{a} \\
(.02, .34)\end{array}$ \\
\hline Protestant & $\begin{array}{l}.19 * \\
(.04, .33)\end{array}$ & $\begin{array}{l}.24^{*^{\mathrm{a}}} \\
(.05, .43)\end{array}$ & $.10^{\mathrm{a}}$ \\
\hline Non-Catholic Private Schools & $\begin{array}{l}.21 * * \\
(.07, .35)\end{array}$ & $\begin{array}{l}.21 * * \mathrm{~b} \\
(.07, .35)\end{array}$ & NA \\
\hline
\end{tabular}

.05 level of probability. In addition, the Protestant student advantage over public school students was not statistically significant. There were no nonstandardized data from those studies that distinguished only between Catholic and non-Catholic private schools.

Table 3 indicates the effects for students attending Catholic, Protestant, and non-Catholic private schools using Model B. The results indicate that excluding those studies that included variables in their analysis that tended to also capture some of the influence of religious schools raised the effect sizes for overall achievement for both Catholic and Protestant schools by .02 of a standard deviation to .19 and .21 for Catholic and Protestant school students, respectively. The effect sizes for academic achievement also rose for Catholic and Protestant school students by .02 standard deviation units to .18 and .26 of a standard deviation unit. However, Protestant, mostly Evangelical, school students maintained a .08 advantage over their Catholic school counterparts. The difference between these two regression coefficients was still statistically significant at the .05 level of probability. The use of Model B did not influence the results for non-standardized measures.

Regarding the research question $\mathrm{D}$, there were no statistically significant differences between the results presented thus far and those that emerged when adjusting for the quality of the study, randomization, the year of the study, or the age of the students. 
Table 3

Effect Sizes of Catholic, Protestant, and Non-Catholic Private Schools Using Model B

\begin{tabular}{|c|c|c|c|}
\hline & $\begin{array}{c}\text { Overall } \\
\text { educational } \\
\text { outcomes }\end{array}$ & $\begin{array}{c}\text { Achievement } \\
\text { tests }\end{array}$ & $\begin{array}{c}\text { Other } \\
\text { measures }\end{array}$ \\
\hline Catholic & $\begin{array}{c}.19^{* *} \\
(.08, .30)\end{array}$ & $\begin{array}{l}.18 * * \text { a b } \\
(.07, .29)\end{array}$ & $\begin{array}{c}.18^{* \mathrm{a}} \\
(.02, .34)\end{array}$ \\
\hline Protestant & $\begin{array}{c}.21 * * \\
(.07, .35)\end{array}$ & $\begin{array}{c}.26 * *^{\mathrm{a}} \\
(.07, .45)\end{array}$ & $.10^{\mathrm{a}}$ \\
\hline Non-Catholic private schools & $\begin{array}{c}.21 * * \\
(.07, .35)\end{array}$ & $\begin{array}{c}.21 * * \mathrm{~b} \\
(.07, .35)\end{array}$ & NA \\
\hline
\end{tabular}

Note. $* p<.05 ; * * p<.01 ; * * * p<.001 ; * * * * p<.0001$

$\mathrm{a}$ or $\mathrm{b}-$ Effect sizes are statistically significant from the corresponding regression

coefficient from other category with the same letter

Table 4 lists the standardized achievement test results by subject (reading, mathematics, and other subjects) using Model B. Consistent, with the standardized achievement test results mentioned earlier, Protestant school students possessed an advantage over their counterparts in Catholic schools. Nevertheless, the differences between Catholic and non-Catholic school students were not statistically significant. However, all three groups of students maintained a consistent advantage over public school students.

\section{Discussion}

The results indicate that Catholic and Protestant school students have about the same academic advantage over their counterparts in public schools. However, the pattern of more specific academic measures is quite different. Protestant school students did better on academic tests than did Catholic school students. However, Catholic students did better than Protestant school students on non-standardized measures.

The results of this meta-analysis suggest that Catholic and Protestant school educators can learn from one another. These findings may indicate that students from Protestant, mostly Evangelical, schools may obtain a broader range of knowledge than their counterparts in Catholic schools. However, Catholic school students, given that they are less likely than children in Protestant schools to be held back and more likely to take demanding courses, may function in a more supportive environment than Protestant school 
Table 4

Effect Sizes of Catholic, Protestant, and Non-Catholic Private Schools Using Model B

Standardized achievement tests

\begin{tabular}{lccc}
\hline & Reading & Math & Other \\
\hline Catholic & $.18^{* *}$ a b & $.17^{\mathrm{a}}$ & $.16^{*^{\mathrm{a}}}$ \\
& $(.01, .35)$ & $(.01, .33)$ & $(.01, .31)$ \\
Protestant & $.27^{\mathrm{a}}$ & $.29 *^{\mathrm{a}}$ & $.23^{\mathrm{a}}$ \\
& $(.02, .52)$ & $(.08, .50)$ & $(.02, .44)$ \\
Non-Catholic private schools & $.21^{*}$ & $.22^{*}$ & $.20^{*}$ \\
& $(.03, .39)$ & $(.04, .40)$ & $(.02, .38)$ \\
& & & \\
\hline
\end{tabular}

Note. $\quad * p<.05 ; * * p<.01 ; * * * p<.001 ; * * * * p<.0001$

$\mathrm{a}$ or $\mathrm{b}$ - Effect sizes are statistically significant from the corresponding regression

coefficient from other category with the same letter.

students. Hopefully, these results will encourage greater communication and cooperation between Christian educators.

To the degree that Catholic and other religious schools may have a somewhat different set of strengths, it would be beneficial for both groups to learn from each other. In fact, given that different kinds of Christian schools, in particular, have similar goals and perspectives, the potential for learning from each other is enhanced. A growing number of religious leaders are calling on Catholic and Protestant churches and schools to collaborate more closely on a copious number of issues (Kelly, 1981; Lynch, 1998; Reimer, 2004). The idea behind these exhortations is that the Christian community can become more efficacious and puissant if cooperation is enhanced. There is a growing awareness among religious leaders and educators that both Catholics and Protestants will benefit if each group focuses on the good of the Christian community as a whole rather than directing too much attention only on the welfare of its nationwide membership (Kelly, 1981; Lynch, 1998; Reimer, 2004). Moreover, to the extent that Catholics and Protestants cooperate with the goal of building better schools, not only will the Christian community benefit, but the entire nation and the world will reap advantages as well.

If, in fact, Catholic and Protestant school educators can learn from one another it is conceivable that the scholastic futures of both groups may be enhanced. This is particularly true regarding the potential for school choice. 
To the extent that Catholic and Protestant educators learn from one another, the religious school advantage over their public school counterparts may increase. Consequently, this could improve the public's perception of school choice. An improved public perception of school choice could enhance the likelihood that choice programs will emerge in subsequent years. This could be a boon for Christian education's future in America.

As it stands now, many Catholic educators in particular are concerned about the financial plight of numerous parochial schools residing in inner cities and in poor rural areas (Borja \& Branscom, 2005; Connell, 2000). Unfortunately, over the last decade or more many of these schools have had to close because of lack of resources or low enrollment (Borja \& Branscom, 2005; Connell, 2000). Educators hypothesize that many Americans are finding it increasingly difficult concurrently to pay for local school taxes and private school tuition (Chubb \& Moe, 1990; Jeynes, 2000, 2007; Jeynes \& Naylor, 2007; Lawton, 2001). A logical solution to this quandary is to initiate an abundance of school choice programs that will offer Americans either a tax break or a voucher to facilitate sending their children to Christian schools (Chubb \& Moe, 1990; Jeynes, 2000, 2007; Jeynes \& Naylor, 2007; Lawton, 2001). To the extent that Catholic and Protestant schools can work in concert to improve their schools and develop a common strategy to promote school choice programs, not only will these religious schools receive financial succor but also the broader American education system will benefit, because more children will be attending high-quality Christian schools.

\section{Limitations of Conclusions}

One should keep in mind that although this analysis indicates that students from Catholic and Protestant schools demonstrate different patterns in achievement, one should note that there is a great diversity in both Catholic and Protestant schools (Hunt, 2000; Welch, Sikkink, Sartain, \& Bond, 2004). This fact is especially ostensible in the case of Protestant schools because there are many different denominations that rest under the umbrella of what social scientists call Protestant schools (Hunt, 2000; Welch et al., 2004). Beyond this, labels common among Protestants, such as born-again Christians and Evangelicals, sponsor a large number of schools that transcend denominational lines. Concurrently, one can also argue that Catholic schools possess a substantial degree of diversity (Hunt, 2000; Welch et al., 2004). For example, Catholic schools in largely Irish and Italian sections of the Northeast are considerably different from Catholic schools with large percentages of Hispanic students in the Southwest (Hunt, 2000). 
In addition, large data sets such as the National Education Longitudinal Study (NELS) data set, a highly respected nationally representative student data set from which many of these studies were drawn, generally do not distinguish between most of the major denominations within Protestantism. Consequently, although one can argue from this research that there are certain academic truths that Catholics and Protestants can learn from each other generally, it is difficult to extend this finding to specific schools. It is important to remember that data from nationwide data sets reflect national trends and are not situation specific or even denominationally specific, at least when it comes to Protestant schools (Welch et al., 2004). Data from the National Assessment of Education Progress (NAEP) does distinguish between Protestant groups, such as Baptists and Lutherans, to some extent (Perie, Vanneman, \& Goldstein, 2005). The NAEP results from 2000-2005 indicate that Lutheran school students, which are quite numerous, somewhat outperform other Catholic and Protestant school students. Moreover, if one excludes Lutheran schools from the analysis, Catholic school students somewhat outperform other Protestant school students. Although these findings are somewhat helpful in understanding denominational differences, they probably do not add as much insight as it might appear. Lutheran schools are most numerous in the northern Midwest, which generally possesses the highest average achievement test scores, and the remaining Protestant denominations are often strongest in the South, where achievement test scores are lower than the national average (Snyder, Tan, \& Hoffman, 2006). Hence, the advantage of going to a Lutheran school in the North versus a public school in the same area may be no greater than attending a Catholic or other Protestant school.

Finally, one should also note that in a meta-analysis one is limited to studying the specific variables that the researchers chose to include in each study. Although in nearly every study the researchers included variables such as SES, gender, and race, there were certain variables such as geographical location and specific denomination that were of interest but could not be addressed in this meta-analysis.

\section{The Need to Meet, Collaborate, and Exchange Ideas}

Although the extent to which Catholic and Protestant schools differ likely varies by Protestant denomination and geographical location, the findings of this study encourage greater dialogue and collaboration among those of the Catholic and Protestant faiths in regard to improving educational outcomes. Increasingly, Catholics and Protestants have learned that they can find more common ground than they previously realized in addressing the nation's moral 
ills, standing for truth and justice, and improving life for the homeless and those dwelling in the inner city (Hoffman \& Miller, 1997; "Religious Right," 2000; Welsh, 2004). It is logical that both Catholics and Protestants would have much to gain if they collaborated more in education. Some suggestions for dialogue and collaboration include regularly visiting one another's schools, joint Catholic-Protestant conferences on how to improve education, and collaboration in academic research in order to maximize educational and behavioral outcomes. To the extent that this is done, it would seem that a winwin situation would result.

\section{The Need for Further Research}

Given that there has been relatively little research comparing the outcomes, cultures, and strengths of Catholic and Protestant schools, it is hoped that this paper will enhance the likelihood of future endeavors in this sphere. Further research that examines both the similarities and differences in educational philosophy, pedagogy, and principles of classroom management will no doubt strengthen the practice of religious education. This study should foster further research to examine the differing patterns of achievement. A number of questions can be addressed, including the following: Do these differences hold across all or most Catholic dioceses and different Protestant denominations? Are some of the differences explained by the geographical location of the schools examined? Are there somewhat different philosophies of education that explain these differences between Catholic and Protestant schools?

In future research, social scientists would be wise to focus on helping to explain the reasons for the Catholic and Protestant school student academic advantages over their public school counterparts. Recent research has contributed to the research community's understanding of why religious schools, broadly defined, in America yield higher scholastic results than do public schools (Jeynes, 2002c). However, it is conceivable that there are different strengths in the Protestant and Catholic rubrics that nevertheless yield similar academic advantages. Moreover, given the diversity among Protestant schools, future research should also address whether there are different strengths and weaknesses that are present among these various kinds of schools. To be sure, a considerable list of similarities will emerge in the results because Catholics and Protestants often have similar worldviews and educational paradigms. Nevertheless, if one is to contribute to maximizing the benefit of Catholic and Protestant educators learning from one another, researchers should seek to discern the differences as well. Throughout all these new efforts, if there emerges 
a new sense of collaboration that seeks to maximize mutual benefit, religious education will no doubt become even more efficacious than it is today.

\section{References}

\section{References marked with an asterisk indicate studies included in the meta-analysis.}

*Alexander, K. L., \& Pallas, A. M. (1983). Private schools and public policy: New evidence on cognitive achievement in public and private schools. Sociology of Education, 56(4), 170-182.

*Alexander, K. L., \& Pallas, A. M. (1985). School sector and cognitive performance: When is a little a little? Sociology of Education, 58(2), 115-128.

Bahr, S. J., Hawks, R. D., \& Wang, G. (1993). Family and religious influences on adolescent substance abuse. Youth and Society, 24(1), 443-465.

*Bauernfeind, R. H., \& Blumenfeld, W. S. (1963). A comparison of achievement scores of publicschool and Catholic-school pupils. Educational and Psychological Measurement, 23(2), 331336.

Beck, S. H., Cole, B. S., \& Hammond, J. A. (1991). Religious heritage and premarital sex: Evidence from a national sample of young adults. Journal for the Scientific Study of Religion, 30(2), 173180.

*Bodenhausen, J. (1989, March). Do public and private schools differ in the performance of their students on advanced placement tests? Paper presented at the annual meeting of the American Educational Research Association, San Francisco. (ERIC Document Reproduction Service No. ED312279)

Borja, R. R., \& Branscom, M. (2005). A spiritual investment. Education Week, 24(24), 34-37.

Brownfield, B., \& Sorenson, A. M. (1991). Religion and drug use among adolescents: A social support conceptualization and interpretation. Deviant Behavior, 12(3), 259-276.

*Brutsaert, H. (1998). Home and school influences on academic performance: State and Catholic elementary schools in Belgium compared. Educational Review, 50(1), 37-43.

Bryk, A. S., Lee, V. E., \& Holland, P. B. (1993). Catholic schools and the common good. Cambridge, MA: Harvard University Press.

*Bryk, A. S., \& Thum, Y. M. (1989). The effects of high school organization on dropping out: An exploratory investigation. American Educational Research Journal, 26(3), 353-383.

Busto, R. V. (1996). The gospel according to the model minority?: Hazarding an interpretation of Asian American Evangelical college students. Amerasia Journal, 22(1), 133-147.

*Carpenter, P. (1985). Type of school and academic achievement. The Australian and New Zealand Journal of Sociology, 21(2), 219-236.

Chubb, J. E., \& Moe, T. M. (1990). Politics, markets, and America's schools. Washington, DC: Brookings Institute.

Cochran, J. K. (1992). The effects of religiosity on adolescent self-reported frequency of drug and alcohol use. Journal of Drug Issues, 22(1), 91-104.

Cochran, J. K., Beeghley, L., \& Bock, E. W. (1992). The influence of religious stability and homogamy on the relationship between religiosity and alcohol use among Protestants. Journal for the Scientific Study of Religion, 31(4), 441-456.

Coleman, J. S. (1988). "Social capital" and schools: One reason for higher private school achievement. Education Digest, 53(8), 6-9.

*Coleman, J. S., Hoffer, T., \& Kilgore, S. (1981). Public and private schools. Washington, DC: U.S. Department of Education, National Center for Education Statistics.

*Coleman, J. S., Hoffer, T., \& Kilgore, S. (1982). High school achievement: Public, Catholic, and private schools compared. New York: Basic Books. 
Connell, C. (2000). Parochial education and public aid: Today's Catholic schools. Washington, DC: Thomas B. Fordham Foundation.

Furnham, A. (1987). Predicting Protestant work ethic beliefs. European Journal of Personality, 1(2), 93-106.

Gamoran, A. (1992). The variable effects of high school tracking. American Sociological Review, $57(6), 812-828$.

Garner, C. W., \& Cole, E. G. (1986). The achievement of students in low-SES settings: An investigation of the relationship between locus of control and field dependence. Urban Education, 21(2), 189-206.

Gaziel, H. H. (1997). Impact of school culture on effectiveness of secondary schools with disadvantaged students. Journal of Educational Research, 90(5), 310-318.

Gerhards, J. (1996). Religion and the spirit of capitalism: A comparison of attitudes toward work and the economic order in the USA and Spain. Berliner Journal für Soziologie, 6(4), 541-549.

Gewirtz, S., Ball, S. J., \& Bowe, R. (1995). Markets, choice, and equity in education. Buckingham, UK: Open University Press.

Giorgi, L., \& Marsh, C. (1990). The Protestant work ethic as a cultural phenomenon. European Journal of Social Psychology, 20(6), 499-517.

Glass, G. V., McGaw, B., \& Smith, M. L. (1981). Meta-analysis in social research. Beverly Hills, CA: Sage.

*Goldberger, A. S., \& Cain, G. G. (1982). The causal analysis of cognitive outcomes in the Coleman, Hoffer, and Kilgore report. Sociology of Education, 55(2/3), 103-122.

*Graetz, B. (1990). Private schools and educational attainment: Cohort and generational effects. Australian Journal of Education, 34(2), 174-191.

Hedges, L. V. (1981). Distribution theory for Glass's estimator of effect size and related estimators. Journal of Educational Statistics, 6(2), 107-128.

*Hoffer, T. B. (1997). Social background and achievement in public and Catholic high schools. Social Psychology of Education, 2(1), 7-23.

*Hoffer, T., Greeley, A. M., \& Coleman, J. S. (1985). Achievement growth in public and Catholic schools. Sociology of Education, 58(2), 74-97.

*Hoffer, T., Greeley, A. M., \& Coleman, J. S. (1987). Catholic high school effects on achievement growth. In E. H. Haertel, T. James, \& H. M. Levin (Eds.), Comparing public and private schools (Vol. 2, pp. 67-88). New York: Falmer Press.

Hoffman, J. P., \& Miller, A. S. (1997). Social and political attitudes among religious groups: Convergence and divergence over time. Journal for the Scientific Study of Religion, 36(1), 5270.

Holman, T. B., \& Harding, J. R. (1996). The teachings of nonmarital sexual abstinence and members' sexual attitudes and behaviors: The case of Latter-Day Saints. Review of Religious Research, $38(1), 51-60$.

Hunt, L. L. (2000). Religion and secular status among Hispanics in the United States: Catholicism and the varieties of Hispanic Protestantism. Social Science Quarterly, 81(1), 344-362.

Irvine, J. J., \& Foster, M. (Eds.). (1996). Growing up African American in Catholic schools. New York: Teachers College Press.

Jackson, L. E., \& Coursey, R. D. (1988). The relationship of God control and internal locus of control to intrinsic religious motivation, coping, and purpose in life. Journal for the Scientific Study of Religion, 27(3), 399-410.

Jeynes, W. (1999). The effects of religious commitment on the academic achievement of Black and Hispanic children. Urban Education, 34(4), 458-479.

Jeynes, W. (2000). Assessing school choice: A balanced perspective. Cambridge Journal of Education, 30(2), 223-241.

Jeynes, W. (2002a). Educational policy and the effects of attending a religious school on the academic achievement of children. Educational Policy, 16(3), 406-424.

Jeynes, W. (2002b). A meta-analysis of the effects of attending religious schools and religiosity on Black and Hispanic academic achievement. Education \& Urban Society, 35(1), 27-49. 
Jeynes, W. (2002c). Why religious schools positively impact the academic achievement of children. International Journal of Education and Religion, 3(1), 16-32.

*Jeynes, W. (2003a). The effects of Black and Hispanic twelfth graders living in intact families and being religious on their academic achievement. Urban Education, 38(1), 35-57.

*Jeynes, W. (2003b). Religion, education, and academic success. Greenwich, CT: Information Age.

Jeynes, W. (2005a). The impact of religious schools on the academic achievement of low-SES students. Journal of Empirical Theology, 18(1), 22-40.

Jeynes, W. (2005b). The relationship between urban students attending religious revival services and academic and social outcomes. Education \& Urban Society, 38(1), 3-20.

Jeynes, W. (2007). American educational history: School, society, and the common good. Thousand Oaks, CA: Sage.

Jeynes, W., \& Naylor, W. (2007). Government involvement in religious education: Perspectives from Abraham Kuyper on school choice. Religion \& Education, 34(1), 76-97.

*Johnson, K. A. (1999). Comparing math scores of Black students in DC's public and Catholic schools (Center for Data Analysis Report \#99-08). Washington, DC: Heritage Foundation.

Johnson, S. T. (1992). Extra-school factors in achievement, attainment, and aspiration among junior and senior high school-age African American youth. Journal of Negro Education, 61(1), 99-119.

*Keith, T. Z., \& Page, E. B. (1985). Do Catholic schools improve minority student achievement? American Educational Research Journal, 22(3), 337-349.

Kelly, F. D. (1981). Ecumenical issues within Christian education today. Journal of Ecumenical Studies, 18(4), 578-589.

Lawton, S. B. (2001). Educational finance and school choice in the United States and Canada (Occasional Paper No. 17). New York: National Center for the Study of Privatization in Education.

*Lee, V. E. (1985a). Investigating the relationship between social class and academic achievement in public and Catholic schools: The role of the academic organization of the school. Dissertation Abstracts International, 46(08). (UMI No. 8523333)

*Lee, V. E. (1985b). National assessment of educational progress reading proficiency, 198384: Catholic school results and national averages. Washington, DC: National Catholic Educational Association.

*Lee, V. E. (1986, April). Multilevel causal models for social class and achievement. Paper presented at the annual meeting of the American Educational Research Association, San Francisco.

*Lee, V. E., \& Bryk, A. S. (1989). A multilevel model of the social distribution of high school achievement. Sociology of Education, 62(3), 172-192.

*Lee, V. E., Chen, X., \& Smerdon, B. (1996). The influence of school climate on gender differences in the achievement and engagement of young adolescents. Washington, DC: American Association of University Women Education Foundation. (ERIC Document Reproduction Service No. ED407077)

*Lee, V. E., \& Smith, J. B. (1993). Effects of school restructuring on the achievement and engagement of middle-grade students. Sociology of Education, 66(3), 164-187.

*Lee, V. E., \& Smith, J. B. (1995). Effects of high school restructuring and size on early gains in achievement and engagement. Sociology of Education, 68(4), 241-270.

*Lee, V. E., \& Stewart, C. (1989). National assessment of educational progress proficiency in mathematics and science, 1985-1986: Catholic and public schools compared, final report, 1989. Washington, DC: National Catholic Educational Association.

Lynch, E. A. (1998). Reform and religion in Latin America. Orbis, 42(2), 263-280.

*Marsh, H. W. (1991). Public, Catholic single-sex, and Catholic coeducational high schools: Their effects on achievement, affect, and behaviors. American Journal of Education, 99(3), 320-356.

*Marsh, H. W., \& Grayson, D. (1990). Public/Catholic differences in the High School and Beyond data: A multigroup structural equation modeling approach to testing mean differences. Journal of Educational Statistics, 15(3), 199-235.

Miller, B. C., \& Olson, T. D. (1988). Sexual attitudes and behavior of high school students in relation to background and contextual factors. Journal of Sex Research, 24, 194-200. 
Mok, M., \& Flynn, M. (1998). Effect of Catholic school culture on students' achievement in the Higher School Certificate Examination: A multilevel path analysis. Educational Psychology, 18(4), 409-432.

*Morgan, W. R. (1983). Learning and student life quality of public and private school youth. Sociology of Education, 56(4), 187-202.

Morris, A. B. (1994). The academic performance of Catholic schools. School Organization, 14(1), 81-89.

Morris, A. B. (1998). So far, so good: Levels of academic achievement in Catholic schools. Educational Studies, 24(1), 83-94.

Mudrack, P. E. (1992). “Work" or "Leisure?" The Protestant work ethic and participation in an employee fitness program. Journal of Organizational Behavior, 13(1), 81-88.

*Noell, J. (1982). Public and Catholic schools: A reanalysis of "public and private schools." Sociology of Education, 55(2/3), 123-132.

Nylander, A. B., Tung, Y., \& Xu, X. (1996, August). The effect of religion on adolescent drug use in America: An assessment of change, 1976-1992. Paper presented at the American Sociological Association meeting, New York.

*Payne, G., \& Ford, G. (1977). Religion, class, and educational policy. Scottish Educational Studies (Edinburgh), 9(2), 83-99. (ERIC Document Reproduction Service No. 5J17678)

*Perie, M., Vanneman, A., \& Goldstein, A. S. (2005). Student achievement in private schools: Results from NAEP 2000-2005. Washington, DC: U.S. Department of Education, National Center for Education Statistics.

*Raudenbush, S., \& Bryk, A. S. (1986). A hierarchical model for studying school effects. Sociology of Education, 59(1), 1-17.

Reimer, S. H. (2004). Lay cooperation in Canada: Catholic and mainline and conservative Protestant attitudes toward interdenominational cooperation. Journal of Ecumenical Studies, 41(2), 223246.

Religious right backs special role at UN for Catholic church. (2000, May). Church \& State, 53(5), 19.

*Riordan, C. (1985). Public and Catholic schooling: The effects of gender context policy. American Journal of Education, 93(4), 518-540.

Sander, W. (1996). Catholic grade schools and academic achievement. Journal of Human Resources, $31(3), 540-548$.

*Sassenrath, J., Croce, M., \& Penaloza, M. (1984). Private and public school students: Longitudinal achievement differences? American Educational Research Journal, 21(3), 557-563.

*Schneider, W. F. (1965). Comparative achievement of graduates of public and Catholic high schools in their freshman college year. Journal of Educational Research, 59(3), 115-121.

Shrauger, J. S., \& Silverman, R. E. (1971). The relationship of religious background and participation to locus of control. Journal for the Scientific Study of Religion, 10(1), 11-16.

Snyder, T. D., Tan, A. G., \& Hoffman, C. M. (2006). Digest of education statistics, 2005 (NCES 2006-030). Washington, DC: U.S. Department of Education, National Center for Education Statistics.

*Sutton, J. P., \& de Diveira, P. C. M. (1995, April). Differences in critical thinking skills among students educated in public schools, Christian schools, and home schools. Paper presented at the annual meeting of the American Educational Research Association, San Francisco. (ERIC Document Reproduction Service No. ED390147)

*Taylor, R. D., Casten, R., Flickinger, S. M., Roberts, D., \& Fulmore, C. D. (1994). Explaining the performance of African American adolescents. Journal of Research on Adolescence, 4(1), 21-44.

Ter Voert, M. (1993). The effect of religion on work attitudes in the Netherlands. Social Compass, 40(1), 33-44.

*Weaver, C. N. (1971). A comparison of the achievement of graduates of Catholic high schools measured by ACT scores by grade point averages. Journal of Mexican American Studies, 1(2), 97-105. (ERIC Document Reproduction Service No. EJ041759) 
Welch, M. R., Sikkink, D., Sartain, E., \& Bond, C. (2004). Trust in God and trust in man: The ambivalent role of religion in shaping dimensions of social trust. Journal for the Scientific Study of Religion, 43(3), 317-343.

Welsh, R. (2004). Christian unity and our identity as disciples of Christ. Ecumenical Review, 56(1), $142-146$.

*Willms, J. D. (1982). Achievement outcomes in public and private schools: A closer look at the High School and Beyond Data (Report No. IFG-TTC-9). Stanford, CA: Institute for Research on Educational Finance and Governance. (ERIC Document Reproduction Service No. ED224157)

*Willms, J. D. (1985). Catholic-school effects on academic achievement: New evidence from the High School and Beyond Follow-up study. Sociology of Education, 58(2), 98-114.

*Young, D. J., \& Fraser, B. J. (1990). Science achievement of girls in single-sex and co-educational schools. Research in Science and Technological Education, 8(1), 5-20.

William H. Jeynes is a professor in the Department of Education at California State University at Long Beach. Correspondence concerning this article should be sent to Dr. William H. Jeynes, California State University at Long Beach, 1250 Bellflower Blvd., Long Beach, CA 90840. 